\title{
DOBIRÇAN TÜRK AĞZINDA SES OLAYLARI
}

Ergin JABLE*

$\ddot{O} \mathbf{z}$

$\mathrm{Bu}$ çalışmamızı daha önce Dobırçan'da yapmış olduğumuz derleme metinlerimizden örnekler tespit ederek oluşturmaya çalıştık. Çalışmamızın amacı hâlen çok canlı bir şekilde kullanılan Dobırçan Türk Ağzı'nın ses özellikleri içerisinde önemli bir yer teşkil eden ses olaylarını özel olarak ele almak ve bu ses olaylarını oluş biçimlerine göre gözler önüne sermektir. Rumeli Ağızları içerisinde özel bir yeri olan Dobırçan Türk Ağzı'nın ses olayları bakımından da özellik arz ettiğini, ortaya çıkan ses olaylarının Türk dilinin genel karakteri ve tarihî seyri çerçevesinde diğer lehçe, şive ve Anadolu Ağızları'nda meydana gelen ses olayları ile benzerlik ve farklılıklar ortaya koyduğunu görüyoruz. Bu çalışmanın kapsamını aşan bu yön bilahare başka çalışmalarda ele alınabilir. Ancak biz burada sadece Dobırçan Türk Ağzı'nın ses olaylarını ortaya koymaya çalıştık. Bu çalışma, sahada ses kayıt cihazıyla yapılan metin derlemesi, kayıtların çevriyazı alfabesiyle metne aktarılması ve metinde tespit edilen dil malzemesinin Ses Bilgisi bakımından incelemesi sonucunda elde edilmiştir.

Anahtar Sözcükler: Doburçan Türk ağzı, ses olayları, dişlileşme, damaklılaşma, dudaklılaşma.

\section{PHONETIC CHANGES IN DOBURÇAN TURKISH DIALECT}

\begin{abstract}
We have tried to form this study by determining samples from our compilation texts that we did in Doburçan before. The aim of the study is to discuss the phonetic changes which takes an important place in phonetic properties of Doburçan Turkish Dialect that is still used lively today in special. We see that Doburçan Turkish Dialect has a unique place in Rumelian Dialect and also its phonetic changes are notable. Also, the phonetic changes in Doburçan Turkish dialect show similarities and differences with other dialects in Anatolia. This subject which goes beyond the scope of this study can be discussed in other studies; but we have tried to bring phonetic changes of Doburçan Turkish Dialect into light. We hope that this study wills contribute to future studies and classifications. This study is based on the method of text compilation done by sound recording device, converting records into text and analysis of vocabularies determined in the text in terms of Phonetics.
\end{abstract}

Keywords: Doburçan Turkish dialect, phonetic changes, dentalization, palatalization, labialization.

\section{Giriş}

Doburçan, Gilan Belediyesine bağl1, Gilan'ın 12 kilometre doğusunda bulunmaktadır. 1312 hektarlık bir alana sahip olan Doburçan, Kale ve Osoya Dağlarıyla çevrili olup, düz bir arazide kuruludur. Köyün ortasından Perlepnitsa Deresi akar. Verimli bir toprağı vardır. Köyün

\footnotetext{
* Doç. Dr.; Priştine Üniversitesi Filoloji Fakültesi Türk Dili ve Edebiyatı Bölümü, erginj@ gmail.com.
} 
ismi yazılı evraklara göre 1437 yllında "Dobrozani" olarak geçmektedir. 1498 y1lında ise Novobırda kazasına bağlı Doburçan nahiyesinde 59 aile reisi olduğu bilinmektedir. 1530'lu yıllarda Vıçıtırın Livası, Novobırda ve Priştine kazaları haritalarında, Doburçan nahiyesi olarak gösterilmektedir. 1566-1574 yıllarına ait Osmanlı kadastro defterlerinde ise 26 hanenin kayıt olduğu belirtilmiştir. Rivayetlere göre Fatih Sultan Mehmet'in Novobırda fethinden sonra, bir bölük Osmanlı askeri Doburçan'a gelir. Köyün girişinde Sırplarla yapılan çatışma sonucu köyü fetheder. Çatışmada 8 Osmanlı askeri şehit düşer. Şehitlerin anısına da insan boyu büyüklüğünde yuvarlak 8 mezar taşı dikilir. Türk aileleri 16. yüzyılda Tokat, Üsküp, Novobırda, Yanova ve farklı yerlerden Doburçan'a yerleşmişlerdir. Haşanlar (Adlovtsa) ailesi ise, Arnavutluk'un Topoyan kasabasından zengin hayvan sürüleriyle başta Kormiyan'a daha sonra da Doburçan'a yerleşirler. İstatistiki veriler incelendiğinde 19. yüzyılda bölgede 70 Türk ailesinin olduğu gözlenmektedir. 1913 yılında Doburçan'da 820 kişi, 1981 yılında ise 2556 kişinin yaşadığı kayıtlara geçmiştir. ${ }^{1}$ Yakın geçmişte bugünkü Mamuşa gibi çoğunluğu Türk nüfuslu olan Doburçan'da bugün $400^{‘} e$ yakın kişi, toplam 70 kadar Türk ailesi yaşamaktadır. Türkçe eğitimi 1951 yılından bu yana Nazım Hikmet İlköğretim Okulunda hâlen devam etmektedir.

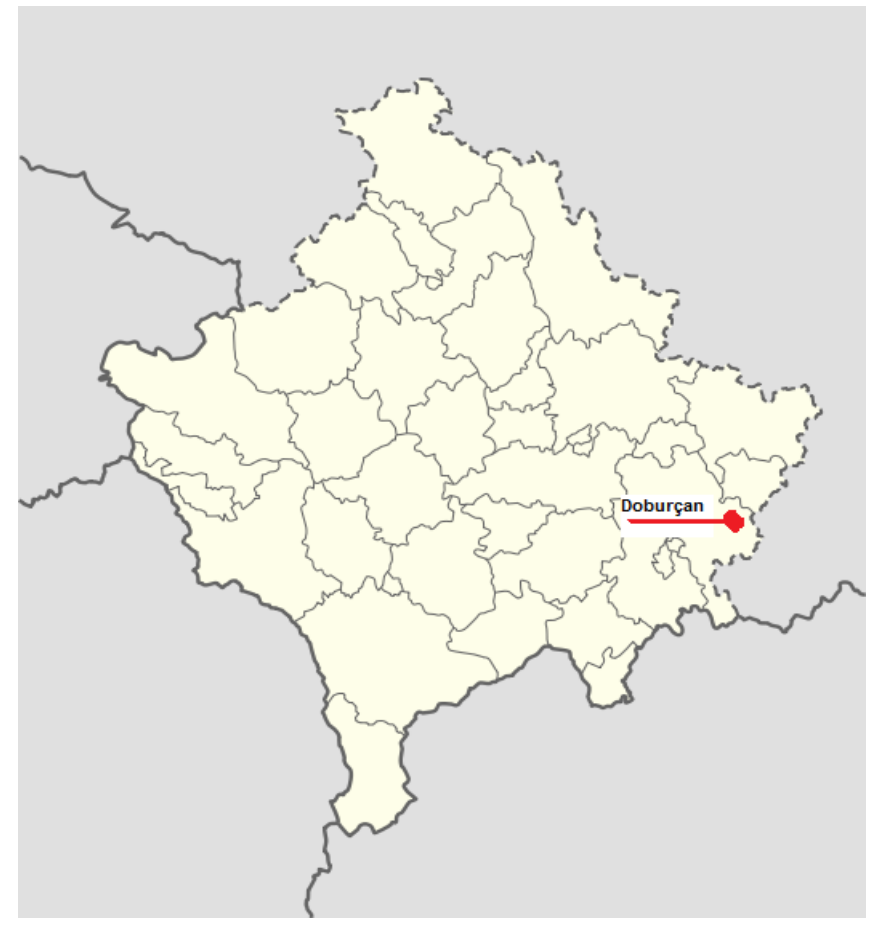

Şekil 1: Doburçan'l gösteren bir harita

\footnotetext{
${ }^{1}$ http://www.kosovaport.com/doburcanda-turkce-egitimde-tehlikeli-gidisat/.
} 


\section{SES BİLGísi}

\subsection{Ses Uyumları}

\subsection{1. Ünlü - Ünlü Uyumsuzluğu}

Türkçede ünlüler, kelimedeki dizilişleri itibarıyla önem derecelerine göre sıralarsak kalınlık-incelik, düzlük-yuvarlaklık, darlık-genişlik bakımlarından bir uyum arz ederler. Dobırçan Türk ağzında aykırı bir durum olarak ünlülerin kelimedeki dizilişleri bakımından uyumsuzluk had safhadadır. Uyumsuzluk, daha çok ünlülerin artlı̆̆ı ve önlüğü bakımından kendini gösterir.

Ünlü-ünlü uyumsuzluğunu kelime kök veya gövdesinde görebiliriz:

alti $<$ altı (OS), ayni $<$ aynı $(\mathrm{HG})^{2}$, dogri $<<$ doğru $(\mathrm{OS})$, ema $<$ ama $(\mathrm{OS})$, etmiştırlar $<<$ etmiştirler (OS), üldi $<<$ öldü (HG), sırpçeyi $<<$ sırpçayı (OS)

Dobırçan Türk ağzında, kalın sıradan ünlü dizisine sahip kelimelere ince ünlülü eklerin getirilmesi veya ince sıradan ünlü dizisine sahip kelimelere kalın ünlülü eklerin getirilmesi uyumsuzluk bakımından rastlanan bir durumdur:

$$
\text { bulidilar }<<\text { buluyordular (OS) }
$$

\section{Ünlü - Ünsüz uyumsuzluğu}

Türkçede ünlü ve ünsüzlerin kelimedeki dizilişleri bakımından nitelik olarak birbirleriyle uyum arz ettikleri görülür. Bu uyum, ses yolunun arka noktasında teşekkül eden ünsüzlerin yanında kalın ünlülerin, ön noktasında teşekkül eden ünsüzlerin yanında ince ünlülerin bulunması şeklinde tezahür eder.

Doburçan Türk ağzında, kelimelerde nadiren ünlü-ünsüz uyumsuzluğu görülür:

$$
\text { kaşik }<\text { kaşık (OS) }
$$

K\# üstsesbiriminin iyelik eki ve yükleme hâl ekini aldığı şekillerde ünlü-ünsüz uyumsuzluğu görülebilir:

bildıgım $<<$ bildiğim $(\mathrm{OS})$

\footnotetext{
${ }^{2}$ Dindar, 1981, s. 126.
} 


\subsection{Ses Olayları}

\subsubsection{Dişlileşme}

Nitelik bakımından, ses organının başka bir noktasında teşekkül eden bir sesin teşekkül noktasının dişe kaymasıdır.

Dişlileşmenin kelimelerde görüldüğü örnekler:

$$
\# \mathrm{c}<\# \mathrm{~K}
$$

cali $<<$ geliyor $(\mathrm{OS})^{3}$, calimiş $<<$ geliyormuş $(\mathrm{OS})^{4}$, cene $<$ gene (yine) $(\mathrm{OS})$, ceri $<$ geri (HG), cibi < gibi (HG), courr $<<$ kafir (OS), cün < gün (OS), cüz $<<$ göz (OS)

$$
\begin{aligned}
& \# \text { ç }<\# \mathbf{k} \\
& \text { çesık }<<\text { kesik (OS), çiyfini }<<\text { keyfini (OS), çüpride }<<\text { köprüde (OS) } \\
& \text { /c/ }</ \mathbf{g} / \\
& \text { ecer }<\text { eğer (OS), inciliz }<\text { ingiliz (OS) } \\
& \text { /ç/ </k/ } \\
& \text { teşviçar }<\text { teşvikar (OS), türçiy }<<\text { türküyü (OS) } \\
& \text { ç\#< k\# } \\
& \text { ilç }<\text { ilk (OS) } \\
& \text { r/ }<\text { ğ/ } \\
& \text { aşari }<<\text { aşağı (OS) } \\
& \text { Dişlileşmenin eklerde görülen örnekleri: }
\end{aligned}
$$

\footnotetext{
${ }^{3}$ Dindar, 1981, s. 124.

${ }^{4}$ Dindar, "Doburçan Lehçesiyle Söylenen Halk Masalları" başlıklı yazısında, metin içinde "gel-" fiil kökünü "cal-“" caldi/calmiş olarak kullanırken, metnin devamında aynı fiil kökünü "col-“olarak kullanmaktadır. Bu özelliğin değișik kullanılması Priştine Türklerinin etkisi görülmektedir. Gilan ve Dobırçan Türkleri kendi aralarında konuştukları sırada fiil kökünü "cal-“ olarak kullanmaktadırlar. Priştine Türkleri ile iç içe yaşayan Gilan ve Dobırçanlılar Priştine Türklerinin etkisinde kalarak "col-“"şeklindeki fiil kökünü kullanmaktadırlar.
} 
açıklarçe $<<$ açıklarken (OS), cirırçe $<<$ girerken (OS), derçen $<<$ derken (HG), enerçen $<<$ inerken $(\mathrm{OS})$, sülerçen $<<$ söylerken $(\mathrm{OS})$, yürürçen $<$ yürürken $(\mathrm{SG})$, yerçen $<$ yerken (HG), zulumçarın $<<$ zulüm karın (OS)

\subsubsection{Damaklılaşma}

Nitelik bakımından, ses organının başka bir noktasında teşekkül eden bir sesin teşekkül noktasının damağa kaymasıdır.

$$
\begin{aligned}
& \text { y\#<r\# } \\
& \text { vay }<\operatorname{var}(O S)
\end{aligned}
$$

Alıntı kelimelerde görülen bu olay, yabancı kelimenin dile katılması sırasında, iki ünlü arasındaki h'lerin, ünlülere en yakın ses olan y’ye dönüştürülmesi şeklinde işleme tabi tutulduğunu gösterir

$$
\begin{aligned}
& / \mathrm{y} /</ \mathrm{h} / \\
& \text { kayirde }<<\text { kahirede (OS), sāyip }<\text { sahip }(\mathrm{OS})^{5} \text {, şeyırınde }<<\text { şehrinde (OS) } \\
& \mathrm{y} /<\mathrm{n} / \\
& \text { agiyın }<<\text { ağabeyin (OS) } \\
& \mathrm{y} /<\breve{\mathrm{g}} / \\
& \text { yeyeni }<\text { yeğeni (OS) } \\
& \mathrm{y} /<\mathrm{k} / \\
& \text { meytep }<\text { mektep (OS) } \\
& \mathrm{y} /<\mathrm{r} / \\
& \text { yalancileyi }<<\text { yalancıları (OS) } \\
& \mathrm{n} /<\mathrm{y} /
\end{aligned}
$$

\footnotetext{
${ }^{5}$ Dindar, 1981, s. 127.
} 


$$
\mathrm{g} /<\mathrm{v} /
$$

ügmek $<<$ övmek (HG), sügmek $<<$ sövmek (OS)

\subsubsection{Dudaklılaşma}

Nitelik bakımından, ses organının başka bir noktasında teşekkül eden bir sesin teşekkül noktasının dudağa kaymasıdır.

$$
\begin{aligned}
& \mathrm{m} /<\mathrm{n} / \\
& \text { çimçi }<<\text { çünkü (OS) }
\end{aligned}
$$

\subsubsection{Patlayıcılaşma}

Nitelik bakımından sızıcı olan bir sesin patlayıcı hâle gelmesidir. Dobırçan Türk ağzında patlayıcılaşma örneklerine seyrek olarak rastlanır.

$$
\mathrm{g} /<\breve{\mathrm{g}} /
$$

doguk $<<$ doğmuş (OS), düşegım $<<$ döşeğim (OS), ogli $<<$ oğlu (OS), sadigın $<<$ sadiğin (OS)

$$
\mathrm{g} /<\mathrm{y} /
$$

anladıgisenız $<<$ anladıysanız (OS)

\subsubsection{Sızıcılaşma}

Nitelik bakımından patlayıcı olan bir sesin sızıcı hâle gelmesidir.

$$
\begin{aligned}
& \text { ş/ <ç/ } \\
& \text { kaşta }<<\text { kaçte }(O S) \\
& \text { s\# < ç\# } \\
& \text { kaş }-<\text { kaç - (OS) }
\end{aligned}
$$

\subsection{6. Ötümsüzleşme}

Nitelik bakımından ötümlü olan bir sesin ötümsüz hâle gelmesidir. Dobırçan Türk ağzında seyrek görülen bir olaydır. 
Ötümsüzleşmenin görüldüğü örnekler:

$\mathrm{t} /<\mathrm{d} /$

ilgiletmedi $<<$ ilgilendirmedi (OS)

$\mathfrak{t} \# \mathbf{z} \#$

çet $<<$ kez (HG)

\subsection{7. Ötümlüleşme}

Nitelik bakımından ötümsüz olan bir sesin ötümlü hâle gelmesidir.

$\# \mathrm{~d}<\# \mathrm{t}$

dane $<$ tane $(\mathrm{OS})$

$\mathrm{g} \#<\mathrm{k} \#$

bag $<$ bak (OS)

$\mathrm{d} \#<\mathrm{t} \#$

memed $<<$ mehmet $(\mathrm{OS})$

$\mathrm{z} /<\mathrm{s} /$

izrail $<$ israil (OS), müderiziydi $<<$ müderrisiydi (OS), namızına $<<$ namusuna (OS)

$\mathrm{g} /<\mathrm{s} /$

üşmegi $<<$ üşümesi $(\mathrm{OS})$

Ekleşmeyle birlikte iki ünlü arasında kalan ötümsüzler, ötümlüleşirler:

$\mathrm{Bu}$ gurupta zikredilen bazı kelimelerin (mesela yog / yok) sonunda hem ötümlü hem ötümsüz altsesbirim bulunabilmektedir. Aynı ek almamış kök veya gövde kelimenin sonunda görülen hem ötümlü hem ötümsüz seslerin varlı̆̆ı keyfi özellik gösterir. Ancak, kelime sonunda sadece ötümsüz bulunduran kelimelerin, ekleşmeyle birlikte kelime sonu ötümlüleşmesine uğradıkları görülür. 
İki kelimenin kaynaşmasıyla, kelimelerden birinde ötümlüleşme gerçekleşebilir:

ojcel- $<<$ hoş gel- (OS)

\subsubsection{Erime}

Bir kelimede ünlüden sonra gelen ünsüzün veya ünlünün -ilk ünlünün açıklığının etkisiyle- niteliğinin silinerek ilk ünlü içinde kaybolmasıdır.

$$
\begin{aligned}
& \emptyset<\mathrm{r \#} \\
& \text { bi }<\text { bir (SG) } \\
& \varnothing<\mathrm{g} / \\
& \text { ertürulun }<<\text { ertuğrulun (OS), sālık }<\text { sağlık (OS) } \\
& \emptyset<\mathrm{n} \# \\
& \text { açıklarçe }<<\text { açıklarken (HG) } \\
& \varnothing<\mathrm{n} / \\
& \text { bulari }<<\text { bunları (OS), sōra }<<\text { sonra (HG) } \\
& \varnothing<\mathrm{r} / \\
& \text { bikaç }<\text { birkaç (HG), kā }<<\text { kadar (OS) } \\
& \varnothing<\text { z\# } \\
& \text { çe }<<\text { kez (OS) } \\
& \varnothing<\text { y/ } \\
& \text { gāri }<\text { gayri (OS) } 7 \text { şedır }<<\text { şeydir (OS) } \\
& \emptyset<\mathrm{h} /
\end{aligned}
$$

amedi $<<$ ahmeti (OS), cennem $<<$ cehennem (OS), māmut $<$ mahmut (OS), tāmina $<<$ tahminen (OS), tariçi < tarihçi (OS), zāmet < zahmet (HG)

\footnotetext{
${ }^{6}$ Dindar, 1981, s. 124.

${ }^{7}$ Dindar, 1981, s. 125.
} 
$\emptyset<\mathrm{h} \#$

padişā $<$ padişah $(\mathrm{OS})$, sali $<$ salih $(\mathrm{OS})$

$\varnothing<\mathrm{k} /$

mitep $<<$ mektep $(\mathrm{SG})$

$\varnothing</ \mathrm{k} /$

türçe $<$ türkçe $(\mathrm{OS})$

$\varnothing<\mathrm{v} /$

tefik $<$ tevfik (OS)

\subsubsection{Yutulma}

Bir kelimedeki bir ünsüzün, kendinden sonra gelen ünlünün açıklığında erimeye fırsat bulamadan kaybolmasidır.

$\emptyset<\mathrm{d} /$

şini $<<$ şimdi $(\mathrm{OS})$

$\varnothing<\# \mathbf{h}$

üzin $<<$ hüzün (OS)

$\varnothing</ \mathrm{h} /$

cumurbaşkani $<<$ cumhurbaşkanı $(\mathrm{HG})$

$\varnothing<\# \mathrm{I}$

stambolda $<<$ istanbulda (OS), ster $<$ ister (OS)

$\mathrm{KVK}>\mathrm{KK}$

brakti $<<$ bıraktı $(\mathrm{HG})^{8}$

${ }^{8}$ Dindar, 1981, s. 126. 
İki kelimenin kaynaşmasıyla, kelimelerden birinde yutulma gerçekleşebilir:

dertüz $<$ dört yüz (OS)

\subsubsection{Büzülme}

Kelime ortasındaki bir veya daha fazla seste gerçekleşen erime veya yutulmalarla meydana gelen ses kayıplarıdır.

bilim $<<$ biliyorum (OS), bilırsenız $<<$ biliyorsanız (OS)

\subsubsection{Düşme}

Kelime sonundaki bir sesin, kendinden önceki sesin açıklı̆̆ında erimeye firsat bulmadan kaybolmasıdır.

$$
\varnothing<\text { I\# }
$$

$$
\begin{aligned}
& \text { çüşey }<<\text { köşeyi }(\mathrm{OS})^{9} \text {, yugoslaviyay }<<\text { yugoslavyayı }(\mathrm{OS}) \\
& \emptyset<\mathrm{h} / \\
& \text { met- }<\text { meth- (OS) }
\end{aligned}
$$

\subsubsection{3. İncelme}

Nitelik bakımından, ses organının arka tarafında teşekkül eden bir ünlünün teşekkül noktasının öne kaymasıdır.

Dobırçan Türk ağzında, art sıradan ünlü dizisine sahip birtakım kelimelerdeki ünlülerin, bazen birinin incelerek ünlü uyumunu bozduğu görülürken bazen de hepsinin incelerek incelik bakımından uyuma girdiği görülebilir:

koyinlar $<$ koyunlar (OS), kutisi $<<$ kutusu $(\mathrm{OS})^{10}$, misir $<<$ misir (OS), pusiy $<<$ pusuyu (OS), tenkıni $<<$ tankını (OS)

\subsubsection{Kalınlaşma}

Nitelik bakımından ses organının ön tarafında teşekkül eden bir sesin teşekkül noktasının dudağa kaymasıdır:

\footnotetext{
${ }^{9}$ Dindar, 1981, s. 125.

${ }^{10}$ Dindar, 1981, s. 125.
} 
Alıntı kelimelerde dikkat çeken ve kelimede art ünlülerin tercih edilmesi şeklinde gözlemleyebildiğimiz bir kalınlaşma vardır:

$$
\begin{aligned}
& \text { a }<\text { e } \\
& \text { halal }<\text { helal (OS) } \\
& \text { cāldınız }<<\text { geldiniz (OS) }
\end{aligned}
$$

\subsubsection{Genişleme}

Kelimede dilin alçak konumunda seslendirilen bir sesin, dilin yüksek konumunda seslendirilir hâle gelmesidir:

$$
\mathrm{e}<\mathrm{i}
$$

deyecēz $<<$ diyeceğiz $(\mathrm{OS})$, nene $<$ nine $(\mathrm{HG})^{11}$

\subsubsection{Daralma}

Kelimede dilin yüksek konumunda seslendirilen bir sesin, dilin alçak konumunda seslendirilir hâle gelmesidir:

$$
\mathrm{i}<\mathrm{e}
$$

çiyfıni $<<$ keyfini (OS), ileştıridilar $<<$ eleştirirdiler (OS), niydım $<<$ neydim (OS), niymiştırlar $<<$ neymiştirler (OS)

$$
\mathrm{U}<\mathrm{O}
$$

kumutani $<<$ komutan 1 (OS)

\subsubsection{Düzleşme}

Nitelik bakımından yuvarlak olan bir ünlünün düz hale gelmesidir.

$$
\mathrm{i}<\mathrm{u}
$$

kaybolmiş $<<$ kaybolmuş (OS)

\footnotetext{
${ }^{11}$ Dindar (1981, s. 125).
} 


$$
\mathrm{e}<\ddot{\mathrm{u}}
$$

$$
\text { güçey }<<\text { göçüyor (OS) }
$$

\subsubsection{Yuvarlaklaşma}

Nitelik bakımından düz olan bir ünlünün yuvarlak hâle gelmesidir. Düzleşmeye nazaran yuvarlaklaşma daha yaygındır:

$$
\begin{aligned}
& \mathrm{U}<\mathrm{I} \\
& \text { evum }<\text { evim }(\mathrm{OS})^{12} \\
& \mathbf{u}<\mathbf{a} \\
& \text { caur }<<\text { kafir (OS) } \\
& \mathbf{o}<\mathbf{e} \\
& \text { novakit }<<\text { ne vakit (OS) }
\end{aligned}
$$

\subsubsection{9. İkizleșme}

Kelime içindeki bir sese (ünsüz), nitelik itibarıyla tıpatıp benzeyen bir sesin türemesi olayıdır:

$$
\begin{aligned}
& \text { ş̧̧ } /<\text { ş/ } \\
& \text { yaşşayanlar }<<\text { yaşayanlar (OS) } \\
& \mathrm{tt} /<\mathrm{t} / \\
& \text { ottuz }<<\text { otuz (OS) }
\end{aligned}
$$

\subsubsection{Tekleşme}

Kelime içinde mevcut olan ünsüz çiftlerinden birinin kaybolmasıdır:

Ekleşmeyle birlikte ortaya çıkan ikizleşme örnekleri de vardır:

$$
\text { yoladi }<<\text { yolla-r-d }(\mathrm{OS})
$$

\footnotetext{
${ }^{12}$ Dindar "Doburçan Lehçesiyle Söylenen Halk Masalları" başlıklı yazısında, "öteye ve kapış-" kelimelerinin "ütüye ve kapuş-" olarak kullanıldığını, burada kelime ortasındaki "öteye" kelimesinin ortasındaki "e" sesinin "ü" sesine ve "kapış-“ kelimesinin ortasındaki "1" sesinin "u” sesine dönüşerek Dobırçan Türk Ağzında yuvarlaklaşma meydana geldiğini görürüz.
} 
Tekleşme olayına genellikle alıntı kelimelerde rastlanır. Dobırçan Türk ağzı bu şekilde, ikiz ünsüz bulunduran yabancı kelimeleri Türkçeleştirme yolunu benimsemiştir:

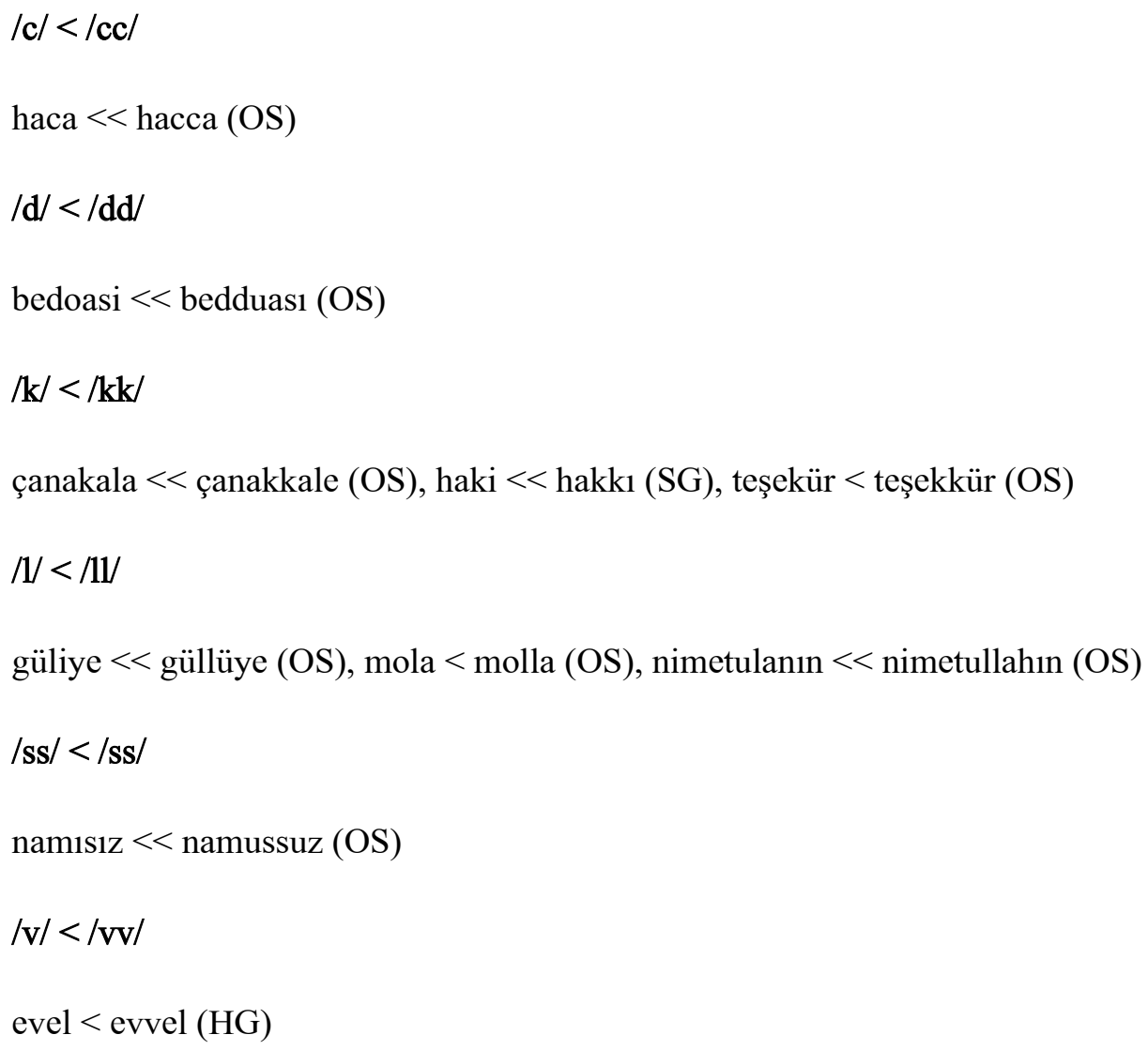

\subsubsection{Toplaşma}

Bir kelimede iki ünlü yan yana gelince Türkçe bu ünlülerin arasında "y" yardımcı ünsüzünü türetir. İkinci ünlü vurgusuz orta hecenin dar ünlüsü olur; bu dar ünlüler kendilerini koruyamadıkları için düşerler. Böylece kelimenin hece sayısında azalma gerçekleşir. Dobırçan Türk ağzında toplaşma olayı, sola toplaşma şeklinde görülmektedir:

aylenın $<<$ ailenin $(\mathrm{OS})$

\subsubsection{Kaynaşma}

Konuşma sırasında, yan yana gelen iki kelimeden birinin son, diğerinin ilk seslerinin anlamca birleşme görülmeden bazı ses olaylarının da etkisiyle kaynaşması sonucunda, bu iki kelimenin, bir kelime gibi söylenmesidir: 
büle $<<$ böyle (HG), memedali $<<$ mehmet ali (OS), ojcel- $<<$ hoş gel- (OS), sekiyüz $<<$ sekiz yüz (OS)

\subsubsection{Ulama}

İki kelimeye ait seslerin, bir kelimeye ait seslerin sahip olduğu zaman aralığı ile seslendirilmesidir.

memedali $<<$ mehmet ali (OS)

\subsubsection{Türeme}

Kelimede daha önce bulunmayan bir sesin türemesi olayıdır:

$\mathrm{I} /<\varnothing$

iliyazın $<<$ ilyasın $(\mathrm{OS})$

$\mathrm{y} /<\varnothing$

beniyım $<<$ benim (SG), deya $<<$ de (OS), sorayan $<<$ soran (OS)

$\# \mathbf{y}<\varnothing$

yüst $<$ üst (OS)

$\mathrm{KK}>\mathrm{KVK}$

alamançe $<<$ almanca (OS), italiyanlar $<$ italyanlar (SG)

\subsubsection{Göçüşme}

Kelimede yan yana bulunan iki sesin niteliklerinden hiçbir şey kaybetmeden yer değiştirmesidir:

brusa $<$ bursa $(\mathrm{OS})^{13}$, kırımzi $<<$ kırmız $(\mathrm{OS})^{14}$

\subsubsection{Benzetme}

Bir sesin, nitelikleri itibarıyla, bir başka sesi kendisine benzetmesidir:

\footnotetext{
${ }^{13}$ Dindar (1981, s. 127) "oturun ve yalnız" kelimeleri anlam olarak aynı fakat ses olayları bakımından son seslerde Göçüşme görülür: "oturni << oturun/yanlız < yalnız”.

${ }^{14}$ Dindar, 1981, s. 125.
} 


\section{Ünsüz benzetmesi:}

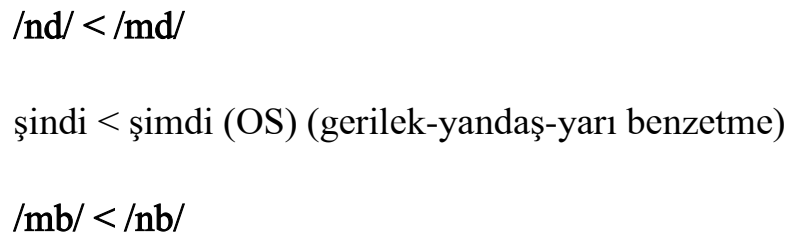

\subsubsection{Palatallaşma}

Yumuşak damak

kaĺilar $<<$ kalıyorlar (OS), kuĺisın $<<$ kulusun (OS)

Ön damak

biøırsenız $<<$ bilirseniz (OS)

\section{Sonuç}

Yapmış olduğumuz incelemeler sonucunda Dobırçan Türk ağzında ünlü - ünlü uyumsuzluğu s1k görülmektedir. Bununla birlikte dişlileşme, damaklılaşma, ötümsüzleşme, ötümlüleşme, erime, yutulma, incelme, kalınlaşma, daralma, yuvarlaklaşma, tekleşme, türeme ve palatallaşma çok s1k görülmektedir.

Oysa dudaklılaşma, patlayıcılaşma, sızıcılaşma, büzülme, derilme, düşme, genişleme, ikizleşme, toplaşma, karışma, kaynaşma, ulama, göçüşme ve benzetme daha nadir görülmektedir.

Dobırçan Türk ağzı bölgesel olarak farklı dillerin etkisinden kurtulamadığı için belki de bu değişiklikleri yaşamaktadır. Daha yüz sene önce İpek Yolu geçidinin ve önemli ticari merkezlerden biri olan Dobırçan'ın yok denecek kadar azalan Türk nüfusu, dil etkileşimi açısından Dobırçan Türk Ağzı ayrıca disiplinler arası araştırma ve incelemelere de muhtaçtır. 
2. Makalede Kullanılan karakterler ve Ses değerleri:

\begin{tabular}{|c|c|}
\hline Karak-ter & Ses Değerleri \\
\hline A & $\mathrm{a}, \mathrm{e}$ \\
\hline $\mathrm{B}$ & $\mathrm{b}, \mathrm{p}$ \\
\hline Ç & $\mathrm{c}, \mathrm{c}$ \\
\hline I & $1, \mathrm{i}$ \\
\hline $\mathrm{K}$ & $\mathrm{k}, \mathrm{g}$ \\
\hline K & ú,à \\
\hline $\mathrm{T}$ & $\mathrm{t}, \mathrm{d}$ \\
\hline $\mathrm{U}$ & $\mathrm{u}, \mathrm{u}$ \\
\hline $\mathrm{V}$ & Ünlü (vokal) \\
\hline \# & $\begin{array}{c}\text { Kelimenin solunda ise kelime } \\
\text { başını, sağında ise kelime } \\
\text { sonunu gösterir. }\end{array}$ \\
\hline / & $\begin{array}{l}\text { Kök ünlüsünden sonra gelen } \\
\text { sesi gösterir. }\end{array}$ \\
\hline$/ /$ & $\begin{array}{l}\text { Bir kelime içindeki sesleri } \\
\text { gösterir. }\end{array}$ \\
\hline$\dot{Z}$ & $\begin{array}{l}\text { Şeklen değil ama fonksiyonca } \\
\text { var olan kelime ve ekleri } \\
\text { gösterir. }\end{array}$ \\
\hline ( ) & $\begin{array}{c}\text { Parantez içindeki sesin ihtiyarî } \\
\text { olduğunu gösterir. }\end{array}$ \\
\hline$>$ & $\begin{array}{c}\text { Ok istikametinde tek aşamalı } \\
\text { değişmeyi gösterir. }\end{array}$ \\
\hline$>>$ & $\begin{array}{l}\text { Ok istikametinde iki veya daha } \\
\text { fazla aşamalı değişmeyi } \\
\text { gösterir. }\end{array}$ \\
\hline+ & İsme eklenmeyi gösterir. \\
\hline- & Fiile eklenmeyi gösterir. \\
\hline A & Normal a \\
\hline
\end{tabular}




\begin{tabular}{|c|c|}
\hline$\overline{\mathrm{a}}$ & Normalden uzun a \\
\hline $\mathrm{C}$ & Normal c \\
\hline Ç & Normal ç \\
\hline $\mathrm{D}$ & Normal d \\
\hline $\mathrm{E}$ & Normal e \\
\hline$\overline{\mathrm{e}}$ & Normalden uzun $\mathrm{e}$ \\
\hline $\mathrm{F}$ & Normal f \\
\hline G & Normal $\mathrm{g}$ \\
\hline$\overline{\mathrm{a}}$ & Tonlu, orta damak g ünsüzü \\
\hline $\mathrm{H}$ & Normal $h$ \\
\hline I & Normal 1 \\
\hline$\overline{\mathrm{I}}$ & Normalden uzun 1 \\
\hline$\dot{\mathrm{I}}$ & Normal i \\
\hline$\overline{\dot{I}}$ & Normalden uzun i \\
\hline $\mathrm{J}$ & Normal $\mathrm{j}$ \\
\hline K & Normal $\mathrm{k}$ \\
\hline K & $\begin{array}{l}\text { Tonsuz, orta damak, patlamalı } \\
\text { k ünsüzü }\end{array}$ \\
\hline $\mathrm{L}$ & Normal 1 \\
\hline Ĺ & Arka damak l'si \\
\hline$\dot{Z}$ & Ön damak l'si \\
\hline M & Normal $\mathrm{m}$ \\
\hline $\mathrm{N}$ & Normal $\mathrm{n}$ \\
\hline $\mathrm{O}$ & Normal o \\
\hline$\overline{\mathrm{O}}$ & Normalden uzun o \\
\hline Ö & Normal ö \\
\hline $\mathrm{P}$ & Normal \\
\hline
\end{tabular}




\begin{tabular}{cc}
\hline$R$ & Normal $\mathrm{r}$ \\
\hline $\mathrm{S}$ & Normal $\mathrm{s}$ \\
\hline $\mathrm{S}$ & $\mathrm{z}-\mathrm{s}$ arası ünsüz \\
\hline $\mathrm{T}$ & Normal $\mathrm{t}$ \\
\hline $\mathrm{U}$ & Normal $\mathrm{u}$ \\
\hline$\ddot{\mathrm{Y}}$ & Normalden uzun u \\
\hline$\ddot{U}$ & Normal $\ddot{\mathrm{u}}$ \\
\hline$\overline{\mathrm{U}}$ & Normalden uzun $\ddot{\mathrm{u}}$ \\
\hline $\mathrm{V}$ & Normal $\mathrm{v}$ \\
\hline $\mathrm{Y}$ & Normal $\mathrm{y}$ \\
\hline $\mathrm{Z}$ & Normal $\mathrm{z}$ \\
\hline
\end{tabular}

3. Kaynak Kişiler:

\begin{tabular}{ccc}
\hline Kısaltma & Adı Soyadı & Yaşı \\
\hline SG & Sami Gaş & 35 \\
HG & Halit Gaş & 50 \\
OS & Osman Sulcevci & 77 \\
\hline
\end{tabular}

\section{Kaynaklar:}

Akalın, M. (1988). Tarihi Türk şiveleri. Ankara.

Aksoy, Ö. A. (1945). Gaziantep ăgzı. İstanbul.

Atalay, B. (1986). Divanü lugati't - Türk dizini IV. Ankara.

Banguoğlu, T. (1986). Türkçe’nin grameri. Ankara.

Caferoğlu, A. (1940). Doğu illerimiz ağızlarından toplamalar. İstanbul.

Caferoğlu, A. (1943). Anadolu ă̆ızlarından toplamalar. İstanbul.

Caferoğlu, A. (1943). Orta Anadolu ă̆ızlarından derlemeler. İstanbul.

Caferoğlu, A. (1944). Sivas ve Tokat illeri ağızlarından derlemeler. İstanbul.

Caferoğlu, A. (1945). Güneydoğu illerimiz ăgızlarından toplamalar. İstanbul. 
Caferoğlu, A. (1946). Kuzeydoğu illerimiz ağızlarından toplamalar. İstanbul.

Caferoğlu, A. (1951). Anadolu illeri ağızlarından derlemeler. İstanbul.

Caferoğlu, A. (1960). Anadolu ve Rumeli ağızlarının bugünkü durumu. VII. T. D. Kurultayında Okunan Bilimsel Bildiriler, Ankara: TDK.

Caferoğlu, A. (1964). Anadolu ve Rumeli ağızları ünlü değişmeleri. Ankara: TDK.

Caferoğlu, A. (1964). Anadolu ve Rumeli ă̆ızlarında ünlü değişmeleri. TDAY.

Dallı, H. (1978). Kuzey - Doğu Bulgaristan Türk ăğzları üzerine araştırmalar. Ankara: TDK.

Dallı, H. (1991). Kuzeydoğu Bulgaristan Türk ağızları üzerine araştırmalar. Ankara.

Dindar, M. (1981). Doburçan lehçesiyle söylenen halk masallar. Priştine.

Ercilasun, A. B. (1963). Kars ili ăğzları. Ankara.

Ergin, M. (1981). Türk dil bilgisi. İstanbul.

Gabain, A. V. (1978). Eski Türkçe'nin grameri. (Çev. Prof. Dr. M. Akalın). Ankara.

Gemalmaz, E. (1978). Erzurum ili ağızları. Erzurum.

Gülensoy, T. (1981). Anadolu ve Rumeli ağızları bibliyografyası. Ankara: Kültür Bakanlığı.

Gülensoy, T. (1987). Rumeli ă̆ızlarının ses bilgisi üzerine bir deneme. Ankara.

Gülensoy, T. (1988). Kütahya ve yöresi ă̆ızları. Ankara.

Gyula, N. (1956). Zur Einleintung der Türkischen Mundarten Bulgariens. Sofia.

Hacıeminoğlu, N. (1984). Türk dilinde fiiller. İstanbul.

Hazai, G. (1960). Beitrage zur kenntnis der Turkischen mundarten mazedoniens. Rocznik Orientalityczny, XXII-2.

Hazai, G. (1960). Rumeli ă̆ızlarının tarihi üzerine. TDAY-B, Ankara: TDK.

Hazai, G. (1963). Rumeli ă̆ızları tarihinin iki kaynağı üzerine. Ankara: TDK.

İbrahim, N. (1997). Cümle bilgisi. Sesler, Üsküp.

İbrahim, N. (1997). Vrapçiş’te ve çevresi Türk ăgzı (Makedonya). Yayımlanmamış Yüksek Lisans Tezi, Ankara: A. Ü. Sosyal Bilimler Enstitüsü. 
Janos, E. (1960). Dinler (Makedonya) Türk ăgzı. Ankara: TDK.

Janos, E. (1962). Kumanova Türk ağzı. TDKY, Nemeth Armağanı, Ankara.

Kakuk, S. (1972). Le dialect Turc d'Ohriden Macédonie, acta orientalia. Academia e Scientarum Hungaricae, Tomus XXVI/2-3.

Kalay, E. (1998). Edirne ili ă̆ızları. Ankara.

Kaleşi, H. (1962). Prizren kao kulturni centar za vreme Turskog perioda. Gjurmime Albanologjike, Priştine.

Karahan, L.(1996). Anadolu ă̆ızlarının sinıflandırılması. Ankara.

Katona, K. L. (1969). Le dialecte Turc de la Macédonie de l'ouest. Ankara: TDK.

Kaya, G. (1986). Yugoslavya Türk halkı yazınına gerçekçi bir bakış. Priştine: Tan Yayınevi.

Korkmaz, Z. (1953). Güney - Batı Anadolu ă̆ızları Batı Anadolu ă̆ızlarında asli vokal uzunlukları hakkında. Ankara: TDAY.

Korkmaz, Z. (1977). Nevşehir ve yöresi ağızları. Ankara.

Kowalski, T. (1926). Osmanisch-Turkische volkslieder aus Mazedonien. WZKM, XXXIII.

Kowalski, T. (1987). Zagadki ludowe Tureckie (Enigmes popularies turques): Prace komisiji oriental istyezny polskiej akademi umeiejetnosci. Ankara.

Mansuroğlu, M. (1960). Edirne ă̆zında yapı, anlam, deyim ve söz dizimi özellikleri. Ankara: TDA Yıllı̆̆ 1.

Morina, İ. (1985). Mamuşa ağzının fonetik özellikleri. ÇEVREN, XII / 49, Priştine.

Morina, İ. (1985). Mamuşa ağzının morfolojik özellikleri. ÇEVREN, XII / 50, Priştine.

Morina, İ. (1985). Mamuşa Türk halkı ağzı üzerinde dil araştırması. Yayınlanmamış Doktora Tezi, İstanbul.

Oktay, A. (2001). Resne ve çevresi Türk ağızların fonetik ve sözlük özellikleri. Yayımlanmamış Yüksek Lisans Tezi, Üsküp: Kiril ve Metodik Üniversitesi, Türk Dili ve Edebiyat1 Bölümü.

Şanlı, C. (1990). Kırklareli ili merkez ilçe köyleri ă̆ızları. Yayınlanmamış Yüksek Lisans Tezi, Edirne. 
Tuna, O. N. (1987). Türk dilbilgisi fonetik ve morfoloji. Malatya.

Tunalıgil, K. C. (1987). Mamuşa Türk ağzı ve özellikleri. XIV / 61, Priştine.

Turan, Z. (2006). Fonetik ve morfoloji ders notları. Sakarya.

Yenibal, S. (1974). Kırklareli ağzı ve hususiyetleri. İ. Ü. Edb. Fak. Mezuniyet Tezi.

Yusuf, S. (1974). Prizren Türkçesinde kimi yabancı ögeler. Priştine.

Yusuf, S. (1984). Arnavutçadan Prizren Türkçesine aktarmalar. Priştine.

Yusuf, S. (1984). Dil çalışmaları. Priştine: Tan Yayınevi.

http://tr.wikipedia.org/wiki/Doburçan,_Kosova

http://www.kosovaport.com/doburcanda-turkce-egitimde-tehlikeli-gidisat/ 